\title{
Regulation and Innovation in the Pharmaceutical Industry: The Case of a New Diabetes Drug
}

\author{
Henry Mora ${ }^{1}$, Gabriela Dutrénit ${ }^{2}$, Alexandre Vera-Cruz ${ }^{3}$ \\ ${ }^{1}$ Ph. D. in Social Sciences, Researcher in Observatorio Colombiano de Ciencia y Tecnología \\ Carrera 72c \# 22a-74, P.C. 110931. Bogotá, Colombia. \\ ${ }^{2}$ Ph.D. in Science Policy Research Unit (SPRU). Professor in the Economics, Management and Policy of \\ Innovation Postgraduate Program, Universidad AutónomaMetropolitana de Mexico. \\ Calzada del Hueso 1100, Coapa, P.C. 04960. Mexico City, Mexico. \\ ${ }^{I}$ Ph.D. in Scientific and Technological Policy, in Science Policy Research Unit (SPRU). Professor in the \\ Economics, Management and Policy of Innovation Postgraduate Program, Universidad \\ AutónomaMetropolitana de México. \\ Calzada del Hueso 1100, Coapa, P.C. 04960. Mexico City, Mexico.
}

\begin{abstract}
This document analyses the effect of the regulation on the pharmaceutical industry's innovation processes. The objective is analyzing the effect of the regulation on the development of an innovative drug produced by a Mexican-based pharmaceutical company. This is an exploratory-type and case study design research. The case is the development of a new diabetes drug. Data was gathered mainly through semistructured interviews to the company's staff, who took part in the innovation project.
\end{abstract}

To understand the effect of the regulation, we started from the analysis of the regulatory requirements that the company had to meet. The different stages of the innovation process were analyzed-it was found that most of the effects are focused into three stages: (i) the stage where human beings are involved for developing tests (clinical trial stage), (ii) the sanitary registration stage, the process in which the drug to be marketed complies with the safety, efficiency, and quality conditions, and (iii) the manufacturing stage, in order to guarantee the appropriate manufacturing of the drug according to good practices.

Regulations lead to both positive and negative effects. Among the positive effects, it is important to highlight the regulations on intellectual property and on the drug's quality. Main negative effects are related to the implementation of the regulation, rather than to the requirements implied. Throughout the innovation process, the regulation caused some delays in the planned activities, leading to cost increases, loss of competitiveness, and uncertainty about the return on investment.

Keywords - Innovation, regulation, pharmaceutical industry, diabetes.

\section{INTRODUCTION}

Over the past two decades, the Mexican pharmaceutical industry has added an average 4.1\% to Mexico's manufacturing GDP. This is the fifth most important activity within the Mexican economy according to its contribution to the gross production of the manufacturing industry [1].

According to several authors, some of the most significant changes that have taken place impacting on the industry - since the last decades of the 20th century — have been: i) the incorporation of Mexico into the General Agreement on Tariffs and Trade in 1986, which led to lowering tariffs on commodities and pharmaceutical active ingredients; ii) the adoption of the Agreement on Trade-Related Aspects of Intellectual Property Rights in 1991, which led to the extension of validity and patent protection, as well as the restriction on using drug patents even when the obtaining process was different; and iii) amendments in the General Health Law (Ley General de Salud), including: the creation of the National Program for Interchangeable Generic Drugs (Programa Nacional de MedicamentosGenéricosIntercambiables - GI) and the definition of the first catalog of this type of drugs in 1998, the publication of the Health Supplies Regulation (Reglamento de Insumos para la Salud) in 1998, as well 


\section{DOI: $\underline{10.51386 / 25815946 / \text { ijsms-v4i6p116 }}$}

as drug advertising, according to their conditions of sale and the public to whom advertising is addressed in $2000[2,3,4]$.

The above items account for the objectives of the national pharmaceutical policy, which has been aimed at increasing the availability and access to both innovative and generic drugs, in the domestic market $[5,6]$, of either domestic or foreign manufacture. In fact, pursuant to the Mexican Ministry of Health (Secretaría de Salud de México - SSA), the timely availability of effective, safe, quality, and affordable drugs contributes to the wellbeing of society, and therefore, on an indirect basis, to Mexico's economic development.

Considering the approach of the national pharmaceutical policy to create conditions to expand drug supply, the analysis of the innovative dynamics of pharmaceutical companies in the country becomes relevant, in order to identify to what extent these companies contribute to such objective, and what factors enhance or limit this performance. Among the relevant factors, the following stand out: i) the relation among the innovation system actors, according to Malerba [5], ii) access to public funding for innovation, iii) technological capabilities of companies, and iv) the regulation that conditions the activities of companies, as well as their relationships with other actors from their environment, among other factors [6].

This research paper focuses on the analysis of the regulation factor. According to ProMéxico [7], regulation is one of the factors pharmaceutical companies take into account when making the decision about whether to develop an innovation project ${ }^{1}$. Pursuant to Blind [8], regulation may be used as a public policy instrument. It would be expected that the regulation complies with the interests of the national pharmaceutical policy and aims at promoting the development of new drugs to meet the Mexican health needs, benefiting the development of innovations by domestic companies. As argued by Peter et al. [9], the relationship between regulation and innovation has been scarcely studied worldwide-little is known about Mexico and its pharmaceutical industry. This paper focuses on this knowledge gap.

The objective of this research is analyzing the effect of the regulation on the development of an innovative drug conducted by a Mexican-based pharmaceutical company. This is an exploratory-type and case study design research to develop a new diabetes drug.

The selection of a diabetes drug was made considering the impact this disease has on the Mexican population. According to Barraza-Lloréns et al. [10], diabetes has become a serious health problem due to its high prevalence, its high degree of mortality, and the disability it causes. Pursuant to the International Diabetes Federation (IDF), Mexico, in 2019, ranked sixth among the countries with the highest number of people living with diabetes, with 12.8 million patients, aged 20-79 years, representing $10.2 \%$ of the national population. Furthermore, it was estimated that, in 2019, 4.8 million people had diabetes, but had not yet been diagnosed. The total number of patients diagnosed with diabetes in Mexico could amount to 17.2 million by 2030 and 22.3 million by 2045 [11]. Furthermore, the evidence has shown that the Mexican population with diabetes has an increased risk of death from Covid-19; more than $37 \%$ of people who died from this virus had diabetes [14].

In addition to this introduction, the paper is divided into seven sections. The second section contains a brief history of the pharmaceutical industry and its main regulatory changes. The third section includes the literature review and the conceptual framework of this paper. The fourth section describes the methodology used for the development of this research. The fifth section includes the company's and the drug's profile. The sixth section contains a discussion of the effects caused by the regulation. Finally, the seventh section contains the conclusions of the study.

\section{Brief History and Main Regulatory Measures of the Mexican Pharmaceutical} INDUSTRY

The Mexican pharmaceutical industry dates back to the post-Revolutionary period (1917-1940), when some national laboratories began producing and marketing brand-name drugs, and large pharmaceutical companies started to invest in Mexico, incorporating subsidiaries within the country [12].

\footnotetext{
${ }^{1}$ According to ProMéxico[7], when innovating, pharmaceutical companies take into account the following aspects: i) public support for
} $R \& D$, ii) intellectual property systems, iii) the regulation required for drug approval, iv) policies of prices, and v) national health systems. 


\section{DOI: $\underline{10.51386 / 25815946 / \text { ijsms-v4i6p116 }}$}

During the Import Substitution Industrialization period (1940-1955), certain conditions arose that are still evident today within the activities and performance of the industry. According to Guzmán and Guzmán [13], in this period, national companies developed relevant technological capabilities to imitate pharmaceutical products, which benefited the domestic production of drug supplies, while large multinational corporations specialized in building research and development (R\&D) capabilities, and then in innovative drug development.

According to several authors, during the creation of the national industry protectionist measures were necessary, in order that national companies managed to consolidate, be competitive, and self-sufficient-so that they did not have to rely on decisions made abroad. On the contrary, incentives were given to multinational corporations to operate in Mexico, with the aim that mainly Mexican-capital corporations would learn through them. However, this rather created technological and economic dependence ties [13, 12]. Although learning was achieved through experience, there was no subsequent evolution towards the development of innovation capabilities [14].

These differences among domestic and multinational corporations continued to grow over time, mainly due to the great influence and power that multinational corporations have over the Mexican economy. This may be seen, i.e., when entering into trade agreements with the purpose of increasing the availability and access to innovative and generic drugs in the domestic market, as set in the objectives of the national pharmaceutical policy [5].

The influence of pharmaceutical multinational corporations is mainly evident in the components of intellectual property protection, which limit the development of incremental innovations by domestic companies. With the execution of these agreements, to meet the commitments made, it has also been necessary to make regulatory changes in the national industry.

According to the Mexican regulatory body, the Federal Commission for the Protection against Sanitary Risk (Comisión Federal para la Protección contra RiesgosSanitarios - Cofepris) [15], and the Mexican Association of Pharmaceutical Research Industries (Asociación Mexicana de Industrias de InvestigaciónFarmacéutica - AMIIF) [16], the main actions that have been taken to comply with trade agreements - in order to increase drug availability and access, as well as to encourage the development of innovative drugs - have been:

- The relationship between the Mexican Institute of Industrial Property (Instituto Mexicano de la Propiedad Industrial - IMPI) and Cofepris, in order to prevent sanitary authorization from being granted to drugs violating intellectual property rights (2003).

- Setting the validity term of the drug sanitary authorization to 5 years ${ }^{2}$ and the conditions for its renewal (2005).

- The determination of bioequivalence and bioavailability requirements for the registration of generic drugs to speed up the entry of this type of drug into the market (2005).

- The removal of a plant requirement throughout the country for the manufacture and registration of drugs (2008).

- Setting the patent-ownership requirement on the drug's active ingredient, or the patent owner's license/approval to exploit it, for the granting of the sanitary authorization (2008).

- The amendment of the legislation, for the registration, manufacture, and marketing of biotechnological drugs (2009).

- Prioritizing the release of generic drugs whose substances relate to the main causes of mortality in Mexicans and that their amount of public and private purchase represents significant savings in public and personal finances (2011).

- Setting the requirements and necessary documentation for the registration of allopathic, biological, and biotechnological drugs in Mexico, through equivalence agreements (2012).

- The authorization of third parties approved to issue opinions - speeding up the waiting time of some processes (2014).

Undoubtedly, these regulatory changes affect the activities performed by Mexican pharmaceutical companies for the development of new drugs, since frequently they are measures taken to protect the results of research conducted by multinational corporations, which, in the end, limit or hinder the innovation process in new

${ }^{2}$ From 1920 to 2005 , drug sanitary authorizations were not to be extended. 


\section{DOI: $\underline{10.51386 / 25815946 / \text { ijsms-v4i6p116 }}$}

companies, as well as in existing local ones, which are still under an imitative process of innovation. This is discussed in detail in the section of results.

\section{Literature ReVIEW AND CONCEPTUAL Framework}

From the institutions' point of view, defined as the rules of the game [17], the regulation involves the institutions established by the Government, in order to directly affecting the behavior of the agents [18]. According to Nelson and Sampat[19], institutions are relevant for at least two reasons: i) because they condition human interaction and in some way specify the actions of the actors, thereby reducing uncertainty and achieving efficient transaction agreements; and ii) because their knowledge discourages or excludes actions that would be more expensive than those complying with the rules of the game.

In this regard, the regulation refers to the diversity of instruments from which the Government sets requirements on companies and society[20]. Therefore, its purpose is to maximize collective well-being, in economic, social, and environmental terms [6], conditioning or specifying the behavior of companies and society. Likewise, the regulation addresses the behavior of companies according to public interests, mainly to: solve market failures [21], address issues of transaction costs, facilitate relations between the Government and companies, and create competition among companies, given the nature of the market (asymmetric information and tension among stakeholders) [18].

Studies on the objectives and impact of the regulation have often been associated with (geographic and sectoral) productivity, growth, quality, and safety, and, recently, with the environment, although not so much with innovation [11]. According to Blind $[8,6]$, the regulation may be considered as a policy instrument to promote innovation, which would be addressed to control the companies' incentives and capabilities to innovate and do business. In this regard, Edquist[22], argues that the regulation influences the innovative behavior of both companies and other agents that interact with companies within the innovation systems framework.

The regulation may hinder innovation when it is excessive, strict, or obsolete [20, 23]. On the contrary, it also may promote it, i.e., by supporting research centers and programs, and by removing barriers to cooperation, facilitating the mobility of qualified staff among organizations and improving relations among companies and universities, inter alia [27, 25, 11]. The World Bank [24] adds other examples: i) public procurement of innovative goods and services to improve the services provided, ii) the acquisition of goods or services for which $\mathrm{R} \& \mathrm{D}$ (pre-business acquisition) is still needed, and iii) when the Government acts as a client for the launch of products intended to be more widely disseminated in the market. In general, the literature reveals that the effects of the regulation on innovation may be both positive and negative, based on the sector, country, type of regulation, size of company or actor from which the analysis is conducted [25, 26, 6, 27].

Some authors who have quantitatively studied how regulation affects innovation identify two types of regulation, according to their objectives: i) economic regulation, which relates to commercial aspects and competition in the market, and ii) social regulation, which relates to the environment and the well-being of society in general $[28,26]$. Other authors consider a third type of (institutional) regulation, which relates to the organization of the market $[25,8,6,27]$ and to the OECD classification [20].

According to Blind [6], the main aspects governed by the economic regulation are: competition, monopolistic positions, mergers and acquisitions, market access, pricing, and the management of public corporations and natural monopolies. On the other hand, by means of social regulation, the protection of the environment, as well as the health and safety of both employees and consumers and producers may be regulated. Lastly, the institutional regulation governs on liability and intellectual property rights, as well as on the protection of employment, migration, and the administration of companies in bankruptcy.Table I shows the main effects found, pursuant to the objective and regulatory aspect.

Based on the literature results, Blind [6] suggests the following proposals so that the effect of the regulation benefits more to innovation: i) focus innovation on regulatory policies, ii) increase the quality of the innovationrelated regulation, iii) improve the implementation of the regulation that encourages innovation, iv) include innovation in the ex-ante and ex post evaluations made on the regulation impact, v) optimize the frequency with which the current regulation is reviewed, vi) coordinate the different regulatory policies to encourage innovation, 


\section{DOI: $\underline{10.51386 / 25815946 / i j s m s-v 4 i 6 p 116}$}

Volume: 4 Issue: 6

vii) prioritize innovation within public policies and as part of the objectives and culture of regulated bodies, and viii) include the regulation into the innovation systems research.

\begin{tabular}{|c|c|c|c|}
\hline 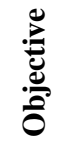 & Aspect & Positive Effects & Negative Effects \\
\hline \multirow{6}{*}{ 苛 } & Competition & $\begin{array}{l}\text { Increases and guarantees incentives for } \\
\text { innovation. }\end{array}$ & $\begin{array}{l}\text { Reduces income for investors and hinders } \\
\text { R\&D cooperation. }\end{array}$ \\
\hline & Antitrust & $\begin{array}{l}\text { Allows competitors to enter the market and } \\
\text { push leading companies. }\end{array}$ & $\begin{array}{l}\text { The leading companies in innovation are } \\
\text { limited by the incentives to invest in } \\
\text { R\&D. }\end{array}$ \\
\hline & $\begin{array}{l}\text { Mergers and } \\
\text { Acquisitions }\end{array}$ & $\begin{array}{l}\text { Allows the efficient acquisition of innovative } \\
\text { companies. }\end{array}$ & $\begin{array}{l}\text { Limits absorption strategies and } \\
\text { innovation incentives. }\end{array}$ \\
\hline & Market Access & $\begin{array}{l}\text { Reduces competition for companies that are } \\
\text { already in the market. }\end{array}$ & $\begin{array}{l}\text { Hinders the entry of potential innovative } \\
\text { companies. }\end{array}$ \\
\hline & Pricing & $\begin{array}{l}\text { Minimum prices reduce risks and guarantee a } \\
\text { minimum volume of sales. Fully free prices } \\
\text { lead to monopolistic prices. }\end{array}$ & $\begin{array}{l}\text { Maximum prices reduce incentives to } \\
\text { innovate. }\end{array}$ \\
\hline & $\begin{array}{l}\text { Public Corporations } \\
\text { and Natural } \\
\text { Monopolies }\end{array}$ & $\begin{array}{l}\text { Promotes progress in productivity by } \\
\text { regulating the rate of return. }\end{array}$ & $\begin{array}{l}\text { Marginal pricing discourages } R \& D \\
\text { investment. }\end{array}$ \\
\hline \multirow{3}{*}{. } & $\begin{array}{l}\text { Environmental } \\
\text { Protection }\end{array}$ & $\begin{array}{l}\text { Encourages the development of new eco- } \\
\text { friendly processes and products by setting } \\
\text { temporary barriers to market entry. }\end{array}$ & $\begin{array}{l}\text { Limits innovation and creates compliance } \\
\text { costs. }\end{array}$ \\
\hline & $\begin{array}{l}\text { Occupational Health } \\
\text { and Safety }\end{array}$ & $\begin{array}{l}\text { Encourages the development of safer } \\
\text { processes by setting temporary barriers to } \\
\text { market entry and to monopoly profits. }\end{array}$ & $\begin{array}{l}\text { Limits innovation and creates compliance } \\
\text { costs. }\end{array}$ \\
\hline & $\begin{array}{l}\text { Consumer and } \\
\text { Producer Safety }\end{array}$ & $\begin{array}{l}\text { Increases the acceptance of new products } \\
\text { among consumers and promotes their use, } \\
\text { encouraging innovation. }\end{array}$ & $\begin{array}{l}\text { Limits innovation and creates compliance } \\
\text { costs. }\end{array}$ \\
\hline \multirow{5}{*}{ 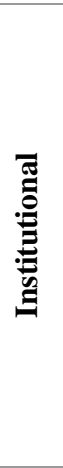 } & $\begin{array}{l}\text { Employment } \\
\text { Protection }\end{array}$ & Job security. & High adjustment costs. \\
\hline & Bankruptcy Laws & $\begin{array}{l}\text { Greater creditor confidence to invest in } \\
\text { innovation. }\end{array}$ & $\begin{array}{l}\text { Restrictions to obtain external funds for } \\
\text { risky investments. }\end{array}$ \\
\hline & $\begin{array}{l}\text { Intellectual Property } \\
\text { Rights }\end{array}$ & $\begin{array}{l}\text { Creates additional incentives to invest in } \mathrm{R} \& \mathrm{D} \\
\text { through the temporary appropriation of } \\
\text { monopolistic rights. }\end{array}$ & $\begin{array}{l}\text { Limits the development and diffusion of } \\
\text { new technologies and products. }\end{array}$ \\
\hline & Liability Rights & $\begin{array}{l}\text { Increases the acceptance of new products } \\
\text { among consumers and promotes their use, } \\
\text { encouraging innovation. }\end{array}$ & $\begin{array}{l}\text { Very high liability risks reduce incentives } \\
\text { to develop and market innovative } \\
\text { products. }\end{array}$ \\
\hline & Immigration & $\begin{array}{l}\text { Immigration of foreign workers increases } \\
\text { pressure on local workers. }\end{array}$ & Integration costs. \\
\hline
\end{tabular}

Table I. Regulation Effects on Innovation, Based on Objectives Source: Own compilation based on Blind [6].

The literature review suggests that most of the studies that have analyzed the regulation-innovation relationship are not conclusive as for the effects found, and that many of these studies have used quantitative methods for the analysis and have focused on assessing the regulation effects on the innovation results, considering some reforms or new regulations nationwide or on an industry-wide basis. Such studies are based on econometric models built from the variables where the effect of regulation is measured.

Particularly in the case of the pharmaceutical industry, the variables that have been considered in most quantitative studies are: i) R\&D investment or investment in other innovation activities, ii) the number of patents applied for and granted, and iii) the number of new registered molecular entities. Conclusions in these 


\section{DOI: $\underline{10.51386 / 25815946 / i j s m s-v 4 i 6 p 116}$}

Volume: 4 Issue: 6

studies have shown, i.e., how much the number of new molecular entities has increased/decreased, the number of applied patents or the R\&D investment, given a specific change in the regulation $[32,33]$.

Unlike quantitative studies, this research seeks to analyze the effect of the regulation on the pharmaceutical industry's innovation using a qualitative methodology. The effect generated by the current regulatory framework is broadly considered, and not just that of a new rule or regulatory change. Also, the effects throughout the innovation process are assessed.

For the development of the research, those variables or aspects that could be affected in the diabetes drug development process were identified and analyzed. These aspects result from the literature review and are associated with both innovation and the company's capabilities to innovate. As shown in Table 2, for each analyzed aspect, the criteria to identify whether the effect was positive or negative was determined.

\begin{tabular}{|c|c|c|c|}
\hline & Aspect & Positive Effect If... & Negative Effect If... \\
\hline \multirow{9}{*}{$\begin{array}{l}\text { Regarding } \\
\text { innovation }\end{array}$} & Planned cost & Decreased & Increased \\
\hline & Product quality & Increased & Decreased \\
\hline & Production & Helped & Hindered \\
\hline & Marketing & Increased & Decreased \\
\hline & Novelty degree & Increased & Decreased \\
\hline & Sale price & Increased & Decreased \\
\hline & Return on investment & Increased & Decreased \\
\hline & Planned time & Decreased & Increased \\
\hline & Intellectual Protection & Helped & Hindered \\
\hline \multirow{6}{*}{$\begin{array}{l}\text { Regarding the } \\
\text { company's } \\
\text { innovation } \\
\text { capabilities }\end{array}$} & Access to funding sources & Helped & Hindered \\
\hline & Access/exchange of information & Helped & Hindered \\
\hline & Competitiveness & Increased & Decreased \\
\hline & Recognition & Helped & Hindered \\
\hline & Relationship with other actors & Helped & Hindered \\
\hline & Innovation strategy & Helped & Hindered \\
\hline
\end{tabular}

Table II. Aspects that May be Affected by the Regulation and Criteria to Determine the Effect Source: Own compilation.

From the identification of the aspects that may be affected by the regulation, Section VI focuses on the effects caused, thus determining the effects for each stage of drug development.

\section{METHODOLOGY}

This is an exploratory-type research as it focuses on an unexplored issue from a qualitative perspective [34]: the relationship between regulation and innovation in the pharmaceutical industry. To identify the relationship between these two variables, the case study methodology was used, which, according to Yin [29], is useful when the limits between the phenomenon and its context are not clearly evident, and when there is little control over events.

The study was based on an innovative diabetes drug developed by a Mexican-based pharmaceutical company. The unit of analysis of the case study was the effect of the regulation at the different stages of the drug development - from the stage of invention of the molecule to its marketing. Interviews were the main source of information, to which other secondary sources were added (scientific and popular papers, documents from the website, and conference videos of the company). As suggested by Yin [29], and since the effects of the regulation are not always measurable and verifiable [11], it is appropriate to draw on the experience of the actors involved.

Interviews were semi-structured and mainly aimed to answer two questions: What were the regulatory requirements - distinguished by stages - that had to be met throughout the innovation process? How did such regulation affect the innovation process? In all, 8 in-depth interviews were conducted between 2018-2019 to key 


\section{DOI: $\underline{10.51386 / 25815946 / \text { ijsms-v4i6p116 }}$}

employees of the company, who took part in the different stages of the drug development process. Stages were defined according to the pharmaceutical company's hierarchical structure and to the proposal of Olaya et al. [30] (See Table III).

\begin{tabular}{|l|l|}
\hline \multicolumn{1}{|c|}{ Stage } & \multicolumn{1}{c|}{ Interviewee's Position } \\
\hline R\&D & R\&D Director \\
\hline Pharmaceutical Development & Pharmaceutical Development Manager \\
\hline Clinical Trials & Clinical Monitoring Manager \\
\hline Sanitary Registration & $\begin{array}{l}\text { Regulatory Affairs Manager } \\
\text { Legal Manager }\end{array}$ \\
\hline Manufacturing & Pharmaceutical Development Manager \\
\hline Marketing & Marketing and Medical Manager \\
\hline Pharmacovigilance & Pharmacovigilance and Medical Manager \\
\hline
\end{tabular}

Table III. Interviews Conducted based on the Development Process Stage and Position Source: Own compilation.

With the information collected, a content analysis was conducted through the specialized Nvivo 12®, software for qualitative information processing. It was a targeted content analysis [31], as the coding categories or nodes were not predefined in the literature for a study of this type. Therefore, a node initial proposal was used, which was refined and complemented from the review of interviews.

Lastly, the list of nodes was made up of: i) the stages of the drug development process, ii) the aspects that could be affected (see Table II), and iii) the objectives of the (economic, social, and institutional) regulation. From the coding of the interviews, information was analyzed based on different forms of grouping according to the nodes ${ }^{3}$.

\section{An INNOVATIVe Diabetes DRUg}

The pharmaceutical company that developed the analyzed innovative drug is a $100 \%$ Mexican-based company. It is classified as a Pharmaceutical Preparation Manufacturing company (code 325412 of the North American Industrial Classification System - NAICS), and it is considered a large establishment, according to the number of employees (over 850). The company conducts R\&D activities on an ongoing basis. 75 employees are devoted to analytical, pre-clinical, and clinical research for the development of innovative products. It invests yearly $10 \%$ of sales in this type of activities.

Since 2004, the company has been designing an alternative drug to metformin, for the reduction of the concentration of blood glucose prescribed to diabetic patients or at risk for diabetes. Today, metformin is the only molecule in the world that controls blood glucose (type 2 diabetes mellitus). Therefore, the drug analyzed herein would be the first Mexican drug to potentially compete within the metformin market (R\&D Director of the pharmaceutical company).

The drug has already been tested on animals and humans. In 2019, it was under the sanitary registration stage, which sanitary authorization for its marketing within the Mexican market was pending. Until then, the drug already had intermediate results such as patents for inventions on the molecule. Also, as it is an innovation project, the company has received public funding for the development of some activities, such as clinical trials, mainly through the Innovation Stimulus ${ }^{4}$ and Tax Incentive Programs ${ }^{5}$.

As for the analysis of the regulation that the company has complied with, most of the rules apply from the clinical trial stage - when the drug begins being tested in humans. During the R\&D stage, the regulation referred to the conditions for animal use in experimental research [38, 39], as well as to the requirements for the protection of intellectual property [40]. In the pharmaceutical development stage, the regulation states the

\footnotetext{
${ }^{3}$ See Appendix 1 for coded nodes and the number of references for each.

${ }^{4}$ The Innovation Stimulus Program financially supports companies investing in research, technology development, and innovation projects aimed at new products, processes, or services.

${ }^{5}$ The Tax Incentive Program is a tax credit equivalent to $30 \%$ of the expenses and investments made by income tax (ISR) taxpayers in technology research and development.
} 


\section{DOI: $\underline{10.51386 / 25815946 / \text { ijsms-v4i6p116 }}$}

requirements to guarantee drug stability, as well as the conditions of its manufacture, to be tested in humans [32, 33].

As of the clinical trials stage, the main regulatory document is the General Health Law, which states the conditions for the development of research in humans, considering the patient's treatment, the drug characteristics, and the responsibilities of the different actors involved [38]. During the sanitary registration stage, the regulation defines the requirements for making the request and verifies compliance with the rules of the previous stages.

Since the drug's sanitary authorization is still pending, manufacturing (on the drug production under Good Manufacturing Practices) and marketing (regarding the conditions for labeling, advertising, and sale of the drug) activities have not been completed yet. On the other hand, the pharmacovigilance activities-which are implemented from the clinical trial stage - are regulated by the Mexican Official Standard (NOM) 220-SSA1 [34]. Such highlight the information to be recorded on adverse effects, risk management, and safety reports.

Pursuant to the analyzed regulation, most of the rule has a social purpose (regarding those described in Table I). It is designed to be able to control the negative externalities that companies may cause on society [28, 26, 6]. In this case, the regulation related to the pharmaceutical company, as for the analyzed drug, seeks to reduce or eliminate negative externalities that may affect the health of the population [35], either due to the drugs available on the market or to the conditions by which such clinical trials are developed.

Likewise, as for the intellectual protection of the molecule and the drug, and as for the definition of rights and responsibilities for the different actors taking part in the clinical research activities, the regulation fulfills an institutional objective. Meanwhile, in the sanitary registration stage, the regulation also has an economic objective - it is a mechanism to either grant or not access of new drugs or competitors to the market [6]. As for the marketing stage that has not been developed, the regulation is expected to have an economic objective, in terms of pricing and conditions for fair competition [28, 26, 6, 27].

\section{RESULTS}

As discussed in Section II, studies on the relationship between regulation and innovation have found that regulation may have both a negative and a positive effect on innovation [25, 26, 27], as well as on the activities conducted to develop innovation [6]. In the case of the analyzed drug, the evidence states the same regarding the drug development process, i.e., in some stages the regulation had a positive effect, while in others it was negative.

According to the evidence analyzed, positive effects were related to: i) the intellectual property protection, ii) the quality of the product and its production process, and iii) the company's innovation strategy ${ }^{6}$ (but in the R\&D stage only). Specifically, and according to the interviewees, the regulation on intellectual property had a positive effect on the development of the drug, as it encouraged the company to invest in R\&D and conduct its innovation strategy, considering the 20 -year protection and exploitation by means of an invention patent (R\&D Director of the pharmaceutical company). This finding confirms what other authors have shown: a positive relationship between the protection of new chemical substances or active compounds and R\&D investment [36].

Also, the finding confirms the literature that states that the regulation may be used as an instrument to promote innovation, by protecting inventions and thus fostering the development of future innovations [8]. In fact, some countries allow the extension of the patent term, under certain conditions, in order to compensate for regulatory obstacles that delay the drug's market entry [37].

The other positive effects of the regulation were found at the pharmaceutical development stage. On the one hand, the continuous updating of the rule, pursuant to the social purpose [35] to protect and care for patients, helped to improve the quality of the drug (Pharmaceutical Development Manager of the pharmaceutical company), as it has been evidenced in other studies [38]. This finding confirms what Reaves also showed [39],

\footnotetext{
${ }^{6}$ Both positive and negative effects were evident in the company's innovation strategy (decision to make future innovations). Positive effects were found in the R\&D stage, while the negative ones were evident in the health certification and marketing stages.
} 


\section{DOI: $\underline{10.51386 / 25815946 / \text { ijsms-v4i6p116 }}$}

in his study of the Orphan Drug Act of 1983 effect on the US pharmaceutical industry, regarding that changes in the regulation may encourage the innovation development to meet the new requirements.

Regulation also caused a positive effect on the production of the drug that was tested in the clinical trial stage. The rule has a certain degree of flexibility that allowed the company to select methods or technologies to comply with it, i.e., to conduct drug stability tests. In this regard, according to Sugarman [40], and Carrigan and Coglianese [41], flexibility may arise from a performance-based regulatory design process where companies are allowed and encouraged to innovate in their processes.

In accordance with the interviewees, the main obstacles created by the regulation were the delays in the planned times, that were common throughout the entire process of the drug development and introduction in the market. The regulation caused delays that translated into cost increases, as well as greater uncertainty about obtaining the sanitary authorization and the drug's market entry date; this would affect the expected cash flows, the expected investment return, and the decision to make future innovations. The stages in which such negative effects were made are described in detail below.

In the pharmaceutical development stage, changes in rules - to strengthen safety, efficiency, and quality of the (previously described) drugs - caused the pharmaceutical company to repeat tests to comply with the new requirements in the production of pilot drug batches. These new tests led to higher costs, as other studies show [51], and to spend more time in the development of the stage's activities. Also, said effects confirm what Stewart [26] stated regarding the fact that the strictness of the changes in the regulation may cause very high compliance costs that could adversely affect innovation.

In the clinical trial stage, delays were related to the approval times of the clinical trial protocols - phase III studies took three months. According to the Clinical Monitoring Manager, delays were related to several factors: i) lack of staff at Cofepris; ii) lack of specification on formats to be used for some procedures, which lead to reprocessing for both parties, and iii) excess of bureaucracy, which may be caused by the imposition of procedural requirements by the regulatory body, as suggested by Carrigan and Coglianese [41].

In the sanitary registration stage, the negative effects occurred due to the delays of the Cofepris to follow-up the procedures for the sanitary authorization. The company was still awaiting the opinion of the New Molecules Committee (Comité de MoléculasNuevas); however, it only received a notification requesting additional information to prove the molecule's safety, efficacy, and superiority. According to the Regulatory Affairs Manager, the notification and delay on the sanitary authorization also involves other negative effects: i) it increases costs, given the new activities to be completed, ii) it delays the product's market entry process, as well as its marketing, and iii) it delays sale income, affecting the competitiveness of the company.

According to the pharmaceutical company, delays are due to the lack of uniformity of the items of the regulatory agency's officials, which pertain, in part: i) to the lack of specificity in the requirements, which allows the rules to be open to interpretation according to the assessor; and ii) to constant changes in the staff, reflecting in turn changes of public servants in the country. Considering the high turnover rate at Cofepris, as Mariscal suggests [18], it is necessary that regulatory bodies act independently with respect to politicians' private interests and to the industry's lobbying, so that the regulation does not become a barrier to innovation, and doesn't generate corruption $[52,53]$.

As a result of the delay on the sanitary authorization, the activities of the manufacturing, and marketing stages have not been completed; neither some of the pharmacovigilance stage. Only activities related to the risk management plan $^{7}$ during the development of clinical trials were completed. As for this plan, negative effects also occurred due to delays in its approval. According to the Pharmacovigilance and Medical Manager, delays arise from the lack of specificity in NOM-220-SSA1 on the structure and minimum elements of the document. This finding, together with others previously described on the lack of specificity in the rules, confirms Peter et al. [9] conclusions stating that the lack of well-defined rules and guidelines may hinder innovation.

\footnotetext{
${ }^{7}$ The activities related to the Risk Management Plan belong to pharmacovigilance activities but are completed during the development of clinical trials.
} 
So far, it has been proved that delays in the approval times of processes hinder the development of innovation. These findings confirm the evidence documented in the literature on the relationship between the time that the sanitary authorization and the decision of future investments takes [54, 33, 51, 26]. However, the evidence of the analyzed drug states this relationship in the opposite way - as has also been concluded in other studies - the delay in the sanitary authorization discourages the company's innovation strategy regarding future investments in $R \& D$ activities $[46,55,56,57]$.

The regulation did not cause any effect throughout the innovation process on the novelty degree and the product's sale price. It did not cause any effect in the access of the company to funding sources, or information exchange either. Also, there neither effect on the relationship with other actors, nor on the recognition of the company.

Although many of the positive and negative effects found confirm the literature, the evidence presented herein suggests that such effects are different for each of the innovation development stages. In sum, Table IV shows the effects caused by the regulation, throughout the development stages of the analyzed drug.

\begin{tabular}{|c|c|c|c|c|c|c|c|}
\hline & \multicolumn{7}{|c|}{ Effect } \\
\hline Aspect $\downarrow$ & $\begin{array}{l}\stackrel{\theta}{8} \\
\simeq\end{array}$ & 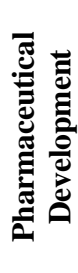 & 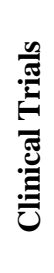 & 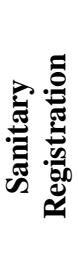 & 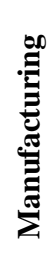 & 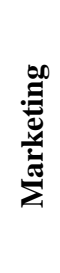 & 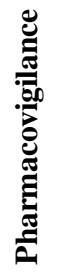 \\
\hline Costs & n.e. & $(-)$ & $(-)$ & $(-)$ & $(-)$ & $(-)$ & $(-)$ \\
\hline Product Quality & n.e. & $(+)$ & n.e. & n.e. & n.e. & n.e. & n.e. \\
\hline Production & n.e. & $(+)$ & n.e. & n.e. & n.e. & n.e. & n.e. \\
\hline Marketing & n.e. & n.e. & n.e. & $(-)$ & n.e. & $(-)$ & n.e. \\
\hline Return on Investment & n.e. & $(-)$ & $(-)$ & $(-)$ & $(-)$ & $(-)$ & $(-)$ \\
\hline Planned Time & n.e. & $(-)$ & $(-)$ & $(-)$ & $(-)$ & $(-)$ & $(-)$ \\
\hline Intellectual Protection & $(+)$ & n.e. & n.e. & n.e. & n.e. & n.e. & n.e. \\
\hline Competitiveness & n.e. & n.e. & n.e. & $(-)$ & $(-)$ & $(-)$ & n.e. \\
\hline Innovation Strategy & $(+)$ & n.e. & n.e. & $(-)$ & n.e. & $(-)$ & n.e. \\
\hline
\end{tabular}

Table 4. Stages and Aspects that Were Affected by the Regulation

Source: Own compilation based on interviews conducted $(2018,2019)$.

(-) negative effect; (+) positive effect; n.e. $=$ no effect.

Specifically, as for the relationship of the company with other actors, although it was expected to be promoted through the regulation — as suggested in the literature [42] — this did not happen. It was proved that the regulation has not governed with an economic objective to promote interaction among organizations regarding supply, to benefit innovation, i.e., to encourage the exchange of information or collaborative innovation [7, 59, 10]. At certain stages - i.e. R\&D - the relationship among actors is not encouraged, and in others-i.e. clinical trials - where this is mandatory, it is considered simply under the criterion of specialization and complementarity [5], where each agent in the system has certain capabilities to perform a particular task.

Furthermore, it was proved that there are other non-regulatory factors affecting the actors' efforts, such as: i) the internal regulations of the organizations, which at certain occasions limited the possibility of a relationship due to the lack of clear procedures for the technology transfer or for the intellectual protection of the results (R\&D Director of the pharmaceutical company); ii) the lack of powers in academic and public institutions to receive external funding and equipment for the collaborative research development [5]; and iii) the lack of a database where both area and field of work of domestic research groups and researchers may be consulted [43], so that, according to their experience, they may be contacted and integrated to corporate research projects. On the contrary, it was proved that other factors, such as access to instruments to promote innovation (i.e. the 


\section{DOI: $\underline{10.51386 / 25815946 / \text { ijsms-v4i6p116 }}$}

Innovation Stimulus Program), benefited and encouraged relationships among actors, particularly in the development of clinical trials.

Also, the case study created evidence on an aspect that does not occur frequently in the literature findings. The regulation may also result in positive effects on other innovation system actors, other than pharmaceutical companies. According to the interviewees, and as proposed by the Mexican pharmaceutical policy [5], research centers that conduct clinical trials have increased, on an over-time basis, their research capabilities and have evolved in order to meet the Cofepris' demands.

The regulation has encouraged this improvement and has attained that clinical trials are performed with higher quality and meeting international standards [44]. This effort by Cofepris to improve clinical research development capabilities follows the same approach as the actions of other foreign agencies, such as the National Health Surveillance Agency of Brazil (ANVISA), which seeks regulatory alignment and consistency to ensure that registered drugs are competitive - in terms of a regulatory perspective - in international markets [62].

Lastly, according to the interviewees, the effects caused by the regulation in the development of this diabetes drug are not different from those that have come out or applied to other new drug projects undertaken by the pharmaceutical company (Pharmaceutical Development Manager of the company). This means that the regulation is not intended to benefit the development of innovative drugs to address the main causes of death in the Mexican population, such as diabetes. This differs from what happens in other countries, such as the United States, where the FDA issued a guideline of recommendations, to minimize the cardiovascular risk that new diabetes drugs could generate [51].

\section{FINAL REFLECTIONS}

This paper-considering the review of the regulatory requirements the company had to comply with in the process of developing an innovative diabetes drug-analyzes the positive and negative effects that the regulation created in the innovation process. In contrast to the literature reviewed, the effects for each stage of the innovation process were analyzed to identify particular effects.

The staged analysis showed that the greatest regulatory burden is focused on the clinical trial stage, i.e. when the drug is tested in humans. In the previous stages, the purpose of the regulation is to set conditions for the use of experimental research animals, to protect the generated inventions (molecule), and to set the manufacturing conditions of the drug to be tested in humans. It is expected that, at the stages coming after clinical trials, the regulation aims to set conditions for drug manufacturing, labeling, advertising, marketing, and reporting of adverse effects, inter alia.

Broadly, the regulation purposes are mainly social - they seek the safety and protection of the population health [35]. Another part of the regulation is focused on institutional objectives [6], especially on the protection of intellectual property and on the rights and obligations of subjects taking part in clinical trials. Lastly, a smaller number of regulatory documents governs through economic objectives [28, 26], mainly to guarantee competitive conditions. This type of regulation would be applied to a greater extent in the marketing stage.

The evidence obtained from the case study confirmed certain findings documented in the literature on the regulation's (positive and negative) double effect on innovation $[25,26,6,27]$. The regulation was found to create some positive effects on the innovative drug development process; however, it, in turn, created other negative effects. Also, it was found that the effects created for this drug do not differ from those that the company has experienced in the development of other drugs. This means that, through the regulation, the government is not benefiting innovative drug development, for any particular disease, except for orphan drugsfor which there are special rules [63].

Positive effects of the regulation were found at the R\&D and pharmaceutical development stages only. As for pharmaceutical development, effects were associated with the drug quality and production for clinical trials, because in many cases the rules set the minimum requirements regarding a procedure, but the technology or method used depends on the companies' decision. That is, the regulation has some flexibility, in terms of the ways to meet the requirements demanded [26]. As for the R\&D stage, positive effects were evidenced that are 


\section{DOI: $\underline{10.51386 / 25815946 / \text { ijsms-v4i6p116 }}$}

being drawn by the regulation on intellectual property, which, as suggested by the literature, encourages future innovation development [36].

On the contrary, for the rest of the development stages, the effects were negative and mainly associated with increases in the response times of the procedures. According to the interviewees - as other studies state-delays are mainly due to gaps and lack of clarity in some aspects of the regulation; therefore, certain requirements are susceptible to interpretation according to the official's criteria and lead to requiring more time or the reprocessing of certain activities by the companies [11].

The findings of this work also confirmed the literature regarding the fact that there is a relationship between the time sanitary authorization takes and the time for innovation development [48, 46, 54, 33, 11, 57]. The case study proved that delays in drug approval hinder innovation by rising costs [51], increasing uncertainty about investment return, and delaying expected cash flows. Therefore, it does not benefit the development of future innovations in the long term.

Also, it bears mentioning that, so far, as other studies have shown, the regulation has neither caused any positive or negative effect on the drug's novelty degree, nor on its sale price $[64,65,56,66]$. As suggested by the literature, the regulation was neither used to promote a relationship between actors and to benefit collaborative innovation $[59,7,58]$.

The analysis also allowed identifying that the regulation has created positive effects on the innovation system - an aspect not shown in the literature. Specifically, the regulation encouraged the development of better research capabilities of those research centers that conduct clinical trials. Furthermore, factors other than the regulation affecting the innovation process were found: the lack of internal regulations for technology transfer and intellectual protection in universities and research centers (R\&D Director of the pharmaceutical company) and the lack of a national database including research groups and researchers, to set collaborative innovation processes [43].

In order to have more evidence on the effects of the regulation on innovations created by the pharmaceutical industry, it would be advisable to extend the analysis to other drugs developed by other pharmaceutical companies. This would allow observing common effects, as well as the companies' characteristics or the environment benefiting or hindering innovation. In the meantime, regarding the company, the observed effects have been similar to those obtained during the development of other innovative drugs.

Also, future research could highlight the negative effects caused by the regulation execution problems, as these problems were almost permanent throughout the innovation process, and, as Blind points out [6], the regulation implementation is one of the most important aspects to promote the relationship between regulation and innovation.

\section{REFERENCES}

[1] Canifarma, "El valor de la Industria Farmacéutica en la economía nacional," Código F, 2016.

[2] E. Dussel, Las industrias farmacéutica y farmacoquímica en México y el Distrito Federal, Ciudad de México: CEPAL, 1999.

[3] S. Yáñez, "Análisis de la estructura de competencia en la industria farmacéutica en México con el modelo de las cinco fuerzas competitivas del mercado de Michael Porter," Instituto Politécnico Nacional, Ciudad de México, 2010.

[4] R. Romay, "La industria farmacéutica nacional y el TLCAN: un esfuerzo industrial contracorriente," in TLCAN 20 años : ¿celebración, desencanto o replanteamiento?, A. Oropeza, Ed., Ciudad de México, Universidad Nacional Autónoma de México/Instituto de Investigaciones Jurídicas, 2014, pp. 313-326.

[5] Secretaría de Salud de México, Hacia una política farmacéutica integral para México, Ciudad de México, 2005.

[6] Cofepris, "Cofepris cumple con su compromiso con la salud de los mexicanos y seguirá trabajando: Sánchez y Tépoz," 19 diciembre 2017b. [Online]. Available: https://www.gob.mx/cofepris/articulos/cofepris-cumple-con-su-compromiso-con-la-saludde-los-mexicanos-y-seguira-trabajando-sanchez-y-tepoz?idiom=es. [Accessed 07 mayo 2019].

[7] F. Malerba, "Sectoral system of innovation: basic concepts," in Sectoral System of Innovation. Concepts, issues and analyses of six 


\section{DOI: $\underline{10.51386 / 25815946 / \mathrm{ijsms}-\mathrm{v} 4 \mathrm{i} 6 \mathrm{p} 116}$}

Volume: 4 Issue: 6

major sectors in Europe, F. Malerba, Ed., Cambridge, Cambridge University Press, 2004, pp. 9-41.

[8] K. Blind, "The impact of regulation on innovation," in Handbook of innovation policy impact, J. Edler, P. Cunningham, A. Gök and P. Shapira, Eds., Massachusetts, Edward Elgar Publishing, 2016, pp. 450-482.

[9] ProMéxico, "Medicamentos genéricos mexicanos. Oportunidades de exportación," ProMéxico, Ciudad de México, 2018.

[10] K. Blind, "The use of regulatory framework for innovation policy," in The theory and practice of innovaton policy: An international research handbook, R. E. Smits, S. Kuhlmann and P. Shapira, Eds., Cheltenham, Edward Elgar Publishing Limited, 2010, pp. 217-246.

[11] V. Peter, G. Veen, A. Doranova and M. Miedzinski, Screening of regulatory framework, T. Group, Ed., Luxembourg: European Union, 2014.

[12] M. Barraza-Lloréns, V. Guajardo-Barrón, J. Picó, R. García, C. Hernández, F. Mora, J. Athié, E. Crable and A. Urtiz, Carga económica de la diabetes mellitus en México, 2013, Ciudad de México: Funsalud, 2015.

[13] IDF, Atlas de la diabetes de la FID, Brussels: Federación Internacional de Diabetes, 2019.

[14] Secretaría de Salud de México, «Covid-19 México,» 0206 2020. [En línea]. Available: https://coronavirus.gob.mx/datos/.

[15] R. Godínez and P. Aceves, "El surgimiento de la industria farmacéutica en México (1917-1940)," Revista Mexicana de Ciencias Farmacéuticas, vol. 45, no. 2, pp. 55-68, 2014.

[16] A. Guzmán and M. V. Guzmán, "¿Poseen capacidades de innovación las empresas farmacéuticas de América Latina? La evidencia de Argentina, Brasil, Cuba y México," Economía: Teoría y Práctica, vol. 1, pp. 131-173, 2009.

[17] J. Solleiro and A. Terán, "Capacidades de innovación y transferencia de tecnología en la industria farmacéutica del Estado de México," in La competitividad de la industria farmacéutica en el Estado de México, J. L. Solleiro, Ed., Ciudad de México, Cambio Tec, 2014, pp. 168-181.

[18] Cofepris, "Historia de la regulación farmacéutica," 2016c. [Online]. Available: http://revistacofepris.salud.gob.mx/n/no5/tramites.html.

[19] AMIIF, "Vinculación entre patentes y registros sanitarios," $28 \quad 09 \quad 2018 . \quad$ [Online]. Available: https://amiif.org/2018/09/28/vinculacion-entre-patentes-y-registros-sanitarios/. [Accessed 17102019 ].

[20] D. North, Institutions, institutional change and economic performance, Cambridge: Cambridge University Press, 1990.

[21] J. Mariscal, Nuevo institucionalismo y regulación. Documento de trabajo, vol. 209, Ciudad de México: Centro de Investigación y Docencia Económica -CIDE, 2008.

[22] R. R. Nelson and B. N. Sampat, "Las instituciones como factor que regula el desempeño económico," Revista de Economía Institucional, no. 5, pp. 17-51, 2001

[23] OCDE, The OECD Report on regulatory reform. Synthesis, Oslo: OECD Publishing, 1997.

[24] P. T. Spiller and M. Tommasi, "The Institutions of Regulation: An Application to Public Utilities," in Handbook of new institutional economics, C. Ménard and M. Shirley, Eds., Springer US, 2005, pp. 515-543.

[25] C. Edquist, "Design of innovation policy through diagnostic analysis: identification of systemic problems (or failures)," Industrial and corporate change, pp. 1-29, 2011

[26] A. Sarkissian, «Drivers and Barriers to Drug Discovery: Insights from a Cross-sectional Survey,» Journal of Pharmaceutical Innovation, pp. 35-49, 2019

[27] L. A. Stewart, "The impact of regulation on innovation in the United States: A cross-industry literature review," January 2010. [Online]. Available: http://www.itif.org/files/2011-impact-regulation-innovation.pdf?_ga=2.111783175.2085396109.15076460931510391532.1507646093. [Accessed 10 Octubre 2017].

[28] World Bank, "Improving the regulatory framework for innovation," in Innovation Policy: A guide por developing countries, Washington, D.C., The World Bank, 2010, pp. 107-134.

[29] E. Brousseau, "The link between regulation and innovation: soe preliminary remarks," in The impact of EU-regulation on innovation of European Industry, F. Leone and J. Hemmelskamp, Eds., Sevilla, Institute for Prospective Technologial Studies, 1998, pp. 93-120.

[30] United Nations, "Training course on STI policies: Fostering Innovation. Participant's Handbook. Working document," United Nations, Geneva, 2017. 


\section{DOI: $\underline{10.51386 / 25815946 / \mathrm{ijsms}-\mathrm{v} 4 \mathrm{i} 6 \mathrm{p} 116}$}

Volume: 4 Issue: 6

[31] F. Leone and J. Hemmelskamp, Eds., The impact of EU-regulation on innovation of European Industry, Sevilla: Institute for Prospective Technologial Studies, 1998, pp. 1-123.

[32] J. Vernon, J. Golec and K. Hughen, "The Economics of Pharmaceutical Price Regulation and Importation: Refocusing the Debate," American Journal of Law \& Medicine, pp. 175-192, 2006.

[33] J. Vernon, J. Golec and C. Nardinelli, "An exploratory study of FDA new drug review times, prescription drug user fee acts, and R\&D spending," The Quarterly Review of Economics and Finance, pp. 1260-1274, 2009.

[34] R. Hernández, C. Fernández and M. d. P. Baptista, Metodología de la investigación, Quinta edición ed., Ciudad de México: McGraw-Hill, 2010.

[35] R. K. Yin, Case study research, design and methods. Applied Social Research Methods Series, Third ed., California: Sage Publications, 2003.

[36] E. S. Olaya, R. G. García, N. S. Torres, D. C. Ferro and S. Torres, "Caracterización del proceso productivo, logístico y regu latorio de los medicamentos," VITAE, pp. 69-82, 2006.

[37] H.-F. Hsieh and S. E. Shannon, "Three Approaches to Qualitative Content Analysis," Qualitative Health Research, vol. 15, no. 9 , pp. $1277-1288,2005$.

[38] Presidencia de los Estados Unidos Mexicanos, Reglamento de la Ley General de Salud en Materia de Investigación para la Salud, 2014

[39] Sagarpa, NOM-062-ZOO-1999. Especificaciones técnicas para la producción, cuidado y uso de los animales de laboratorio, 2001.

[40] Congreso de los Estados Unidos Mexicanos, Ley de la Propiedad Industrial, 2018a.

[41] Cofepris, NOM-059-SSA1-2015. Buenas prácticas de Fabricación de Medicamentos, $2016 \mathrm{a}$.

[42] Cofepris, NOM-073-SSA1-2015. Estabilidad de fármacos y medicamentos, así como de remedios herbolarios, 2016b.

[43] Cofepris, NOM-220-SSA1-2016. Instalación y operación de la farmacovigilancia, 2017a.

[44] J. Abraham and C. Davis, "International and temporal comparative analysis of UK and US drug safety regulation in changing political contexts," Social Science \& Medicine, pp. 1-10, 2020.

[45] V. Grossmann, "Do cost-sharing and entry deregulation curb pharmaceutical innovation?," Journal of Health Economics, pp. 881894,2013

[46] A. Katz, "Pharmaceutical Lemons: Innovation and Regulation in the Drug Industry," Michigan Telecommunications \& Technology Law Review, pp. 1-41, 2007.

[47] K. Bognar, J. A. Romley, J. P. Bae, J. Murray, J. W. Chou and D. N. Lakdawalla, "The role of imperfect surrogate endpoint information in drug approval and reimbursement decisions," Journal of Health Economics, pp. 1-12, 2017.

[48] N. Reaves, "A Model of Effective Health Policy," Journal of Health \& Social Policy, vol. 14, no. 4, pp. 61-71, 2003.

[49] S. D. Sugarman, «Salt, high blood pressure, and performance-based regulation,» Regulation \& Governance, vol. 3, $\mathrm{n}^{\circ}$ 1, pp. 84102,2009

[50] C. Carrigan and C. Coglianese, "The Politics of Regulation: From New Institutionalism to New Governance," Annual Review of Political Science, vol. 14, pp. 107-129, 2011.

[51] J. A. DiMasi, H. G. Grabowski and R. W. Hansen, "Innovation in the pharmaceutical industry: New estimates of R\&D costs," Journal of Health Economics, pp. 20-33, 2016.

[52] T. Vian, "Review of corruption in the health sector: theory, methods and interventions," Health Policy and Planning, p. 83-94, 2007.

[53] S. Al-Mutairi, I. Connerton y R. Dingwall, «Understanding "corruption" in regulatory agencies: The case of food inspection in Saudi Arabia,» Regulation \& Governance, 2019.

[54] J. Abraham and C. Davis, "Interpellative Sociology of Pharmaceuticals: Problems and Challenges for Innovation and Regulation in the 21st Century," Technology Analysis \& Strategic Management, vol. 19, no. 3, pp. 387-402, 2007.

[55] S. Y. Lim y M. Suh, «Product and Process Innovation in the Development Cycle of Biopharmaceuticals,» Journal of Pharmaceutical Innovation, pp. 156-165, 2015.

[56] T. Schwartz, A. Ward, X.-M. Xu and J. Sullivan, "The Impact of Lifting Government Price Controls on Global Pharmaceutical 


\section{DOI: $\underline{10.51386 / 25815946 / \mathrm{ijsms}-v 4 \mathrm{i} 6 \mathrm{p} 116}$}

Volume: 4 Issue: 6

Innovation and Population Health," Value in Health, vol. 21, no. 1, p. 119, 2018.

[57] A. Chorniy, J. Bailey, A. Civan and M. Maloney, Regulatory Review Time and Pharmaceutical R\&D, Arlington: Mercatus Center at George Mason University, 2019.

[58] S. Samford, "Innovation and public space: The developmental possibilities of regulation in the global south," Regulation \& Governance, vol. 9, no. 3, pp. 294-308, 2015.

[59] M. McKelvey, L. Orsenigo and F. Pammolli, "Pharmaceuticals analyzed through the lens of a sectoral innovation system," in Sectoral System of Innovation. Concepts, issues and analyses of six major sectors in Europe, F. Malerba, Ed., Cambridge, Cambridge University Press, 2004, pp. 73-120.

[60] AMIIF, "Semana de innovación 2019," 0304 2019. [Online]. Available: https://amiif.org/semana-de-la-innovacion-2019/.

[61] ICH, "ICH E6 Good Clinical Practice (GCP)," $09 \quad 11 \quad 2016 . \quad$ [Online]. Available: https://www.ich.org/fileadmin/Public_Web_Site/ICH_Products/Guidelines/Efficacy/E6/E6_R2_Step_4_2016_1109.pdf. [Accessed 2208 2019].

[62] C. Favale, A. Vilha, K. Nachiluk, C. Cano and C. Gambôa, "Medicamentos biossimilares: Da regulaçao à promoção do desenvolvimento tecnológico e inovativo pela ANVISA," in Memorias del XVIII Congreso Latino-Iberoamericano de Gestión Tecnológica - ALTEC 2019, Medellín, 2019.

[63] Congreso de los Estados Unidos Mexicanos, Ley General de Salud, 2018b.

[64] P. Barros and L. Nunes, "The impact of pharmaceutical policy measures: An endogenous structural-break approach," Social Science \& Medicine, p. 440-450, 2010.

[65] P. González, I. Macho-Stadler and D. Pérez-Castrillo, "Private versus social incentives for pharmaceutical innovation," Journal of Health Economics, pp. 286-297, 2016.

[66] J. Kennedy, "The Link Between Drug Prices and Research on the Next Generation of Cures," 9 septiembre 2019. [Online]. Available: https://itif.org/publications/2019/09/09/link-between-drug-prices-and-research-next-generation-cures. [Accessed 13 febrero 2020]. 
DOI: $\underline{10.51386 / 25815946 / \mathrm{ijsms}-\mathrm{V} 4 \mathrm{i} 6 \mathrm{p} 116}$

Volume: 4 Issue: 6

November to December 2021

https://www.ijsmsjournal.org

\begin{tabular}{|c|c|}
\hline Regulation Effects on the Product & No. of References \\
\hline Planned Cost & 10 \\
\hline Product Quality & 6 \\
\hline Production & 9 \\
\hline Marketing & 4 \\
\hline Novelty Degree & 3 \\
\hline Sale Price & 2 \\
\hline Return on Investment & 6 \\
\hline Planned Time & 23 \\
\hline Intellectual Protection & 7 \\
\hline Regulation Effects on the Company & No. of References \\
\hline Access to Funding Sources & 2 \\
\hline Access/Exchange of Information & 14 \\
\hline Company's Competitiveness & 12 \\
\hline Company's Recognition & 1 \\
\hline Relationships with Other Innovation System Actors & 21 \\
\hline Innovation Strategy & 7 \\
\hline Regulation Effects based on Objectives & No. of References \\
\hline Economic & 15 \\
\hline Market entry regulation & 9 \\
\hline Competition enhancing & 5 \\
\hline Price regulation & 1 \\
\hline Institutional & 8 \\
\hline Liability law & 5 \\
\hline Intellectual property rights & 3 \\
\hline Social & 25 \\
\hline Consumer safety & 25 \\
\hline Stages of the Development Process & No. of References \\
\hline $\mathrm{R} \& \mathrm{D}$ & 12 \\
\hline Pharmaceutical Development & 20 \\
\hline Clinical Trials & 32 \\
\hline Sanitary Registration and Intellectual Protection & 39 \\
\hline Manufacturing & 13 \\
\hline Marketing & 22 \\
\hline Pharmacovigilance & 25 \\
\hline
\end{tabular}

Appendix 1. Coded Nodes and Number of References for Each Source: Own compilation based on Nvivo 12®. 